\title{
From Knowledge to Knowledges: An Introduction
}

\begin{abstract}
This Introduction outlines changing concepts of knowledge from the Platonic 'justified true belief' to central theses of present-day Knowledge Research, which emphasise the embeddedness of knowledge production in historical, cultural, political, economic, and medial power constellations. Thus, the entanglement of knowledge and power under colonial conditions manifests its legacy in the current deprecation of non-Western knowledge traditions, as critics from India and other postcolonial nations have pointed out. In contradistinction to such hierarchisations of knowledge forms, contemporary Knowledge Research in the West conceptualises knowledge cultures, where propositional and non-propositional knowledge forms - like aesthetic perceptions - under specific conditions are recognised as different, yet equally valid and limited ways of being in and appropriations of the world. As this anthology brings together English and German contributions, the introduction finally offers comprehensive summaries of the individual essays in order to facilitate a panoramic overview of the analyses and central theses gathered in this book for all readers.
\end{abstract}

Zusammenfassung: Die Einleitung skizziert unterschiedliche Wissenskonzepte von der platonischen ,gerechtfertigten wahren Überzeugung ' bis zu zentralen Thesen der gegenwärtigen Wissensforschung, welche die Eingebundenheit jeder Wissensproduktion in historische, kulturelle, politische, ökonomische und mediale Machtkonstellationen betonen. So schlägt sich die Verflochtenheit von Wissen und Macht im Kolonialismus heute in der generellen Geringschätzung nicht-westlicher Wissenstraditionen nieder, wie kritische Stimmen aus Indien und anderen postkolonialen Nationen hervorheben. In Absetzung von solchen Hierarchisierungen von Wissensformen konzeptualisiert die westliche Wissensforschung Wissenskulturen, in denen propositionale und nicht-propositionale Wissensformate - wie zum Beispiel ästhetische Erkenntnisse - als unterschiedliche, jedoch gleichermaßen wertvolle und begrenzte Möglichkeiten des In-der-Welt-Seins und der Aneignung von Welt anerkannt sind. Da diese Anthologie englische und deutsche Aufsätze zusammenbringt, schließt die Einleitung mit ausführlichen Zusammenfassungen der Einzelbeiträge, um allen Leserinnen und Lesern einen Überblick über die hier versammelten Studien und Thesen zu ermöglichen. 


\section{No Knowledge in Knowledge Societies?}

According to Hans N. Weiler, "[t]he more recent debate on the impact of globalization on development and under-development in the world deals prominently with the role of knowledge and research both in sustaining a new globalized order, and in subverting it" (Weiler 2009: 6). On the one hand, the achievements in the wake of scientific discoveries as well as the dissemination of knowledge through educational institutions have brought improvements of health and living conditions for large parts of the world's population, while on the other hand, knowledge has become a contested commodity, considered of paramount importance for the development and well-being of individuals and countries, and therefore framed and steered by political and economic interests.

Leaving this bird's eye perspective, one sees individual lives increasingly regulated and organised by an aggressively market-oriented self-improvement industry, which bombards their consumers with supposedly scientifically approved advice, ranging from physical and psychological health to parenting and ethical lifestyles. Additionally, the internet allows access to medical, religious and philosophical knowledge traditions of non-Western cultures, which some recipients embrace as exotic(ist) remedy for occidental deficiencies, while others consider them as pre-enlightened guess work or mere superstition. Observing this state of affairs, the UNESCO World Report on Knowledge Towards Knowledge Societies states: “As for knowledge societies, while there is general agreement on the appropriateness of the expression, the same cannot be said of the content. Which types of knowledge are we talking about?” (2005: 5)

With the advent of 'fake news', 'alternative facts', and the difficulties of authenticating statements in the so-called social media, the problem to identify reliable knowledge in a host of competing knowledge formations has gained urgent relevance in interpersonal, intercultural and global contexts. But not even the academic sciences can supply clear-cut answers as to what counts as true knowledge: Historians of science, science sociologists, and philosophers of science - often inspired by the seminal work of Bruno Latour (see Latour 1979) - from their various perspectives uphold that definitions of truth are relative, because they are framed by historically and culturally specific concepts of authority, methodology, the state of technologies and medial representation. Yet, despite this relativisation of validity claims on all fronts, politicians increasingly have to rely on scientific knowledge as a basis for far reaching decisions: Challenges like climate change, alternative energies, genetics, epi- and pandemics, as well as the deposition of radioactive waste demand political interventions, which are legitimised by knowledges produced by expert communities and under circumstances mostly far removed from the sphere of politics as well as from the specific sites of intervention, as the essays of Rudolf Stichweh and Konrad Ott in this volume explicate.

Taking this state of affairs as their starting point, in 2014 the working group "Social Legitimation of Knowledge Formations - Comparative Perspectives" (Gesell- 
schaftliche Legitimierung von Wissensbeständen - Vergleichende Perspektiven) was established at the Academy of the Sciences and Humanities in Hamburg in order to "address [...] the questions of how, by whom, and with which legitimation knowledge is produced, disseminated, and regulated" (Lenzen 2011: 2; my translation). The interdisciplinary group comprising ten academic disciplines conducted comparative analyses of various knowledge formations, diachronically between different historical periods as well as synchronically between different disciplines in Western societies, and between different cultures on a global scale. Two central premises framed the respective studies: 1 ) The manifest hierarchy of values accorded to the knowledge of the natural sciences and the humanities in Western societies, between propositional and non-propositional statements, and between Western and non-Western knowledge paradigms are not intrinsically given, but result from powerful constellations of dominant discourses, political and economic interests, technologies and media on an institutional, national and global scale. 2) The value attributed to specific knowledge formations is largely dependent on the legitimatory strategies to justify their claims to truth and validity. These assumptions also informed the international conference Competing Knowledges on a Global Scale in 2017 as well as the Academy Lecture Series Wissen im Widerstreit in 2018/19, from which this volume emerged. For this reason, the introduction will at first expound the two suppositions - namely the linkage of knowledge and power, and the significance of historically specific legitimatory strategies -, before presenting central theses of the ongoing Knowledge Research that form the theoretical background for most of the contributions in this volume. Finally, the individual essays will be summarised comprehensively.

\subsection{Knowledge and Power}

The entanglement of knowledge and power has most influentially been elaborated by Michel Foucault. In his view, knowledge is simultaneously the instrument and the result of the social competition for power. Already in his first lecture course at the Collège de France he comments on Aristotle's assertion that "[a]ll men by nature (phusei) desire to know" (Aristotle qtd. in Foucault 2013: 5), and he voices his hypothesis that "we can articulate this will to know, which has taken the form of a will to truth, not on a subject or on an anonymous force, but on real systems of domination", because "truth is not given in advance; it is produced as an event" (ibid: 4, 198). In "Truth and Power" he expounds:

[T]ruth isn't outside power, or lacking in power: [...] Truth is produced only by virtue of multiple forms of constraint. [...] Each society has its régime of truth [...]: the types of discourse which it accepts and makes function as true; the mechanisms and instances which enable one to distinguish true and false statements, the means by which each is sanctioned; the techniques and procedures accorded value in the acquisition of truth; the status of those who are charged with saying what counts as true. (Foucault 1980: 131) 
The specific ways in which knowledge is connected to issues of power are diverse and often subtle. Thus, knowledge can function as a political instrument, for example when claims to absolute truth are instrumentalised in order to subdue social groups and entire cultures by installing supremacy over specific "kinds of knowledge such as know-how, indigenous knowledge, local knowledge, oral traditions, daily knowledge and so on" (UNESCO 2005: 148). The most blatant examples for this strategy can be found under colonialism, fired by the Eurocentric notion that "all knowledge worth knowing ... [sic] was created in Europe" and that before their colonisation nonEuropean Indigenes had been "sitting on [their] thumbs waiting for enlightenment (Episkenew)” (Lutz 2018: 66). Comaroff and Comaroff explicate:

Euro-American social theory [...] has tended to treat modernity as though it were inseparable from Aufklärung, the rise of Enlightenment reason. [...] together they are assumed to have animated a distinctively European mission to emancipate humankind from its uncivil prehistory, [...] from the thrall of miracle and wonder, enchantment and entropy. (Comaroff/Comaroff 2016: 2)

Enforced by the allegiance of Western notions of knowledge with the ideas of 'civilisation' and 'progress', normative concepts concerning the production and definition of knowledge have been imposed on non-Western knowledge traditions, either forcibly under colonial conditions, or by instruments of institutional and economic coercion in more recent times. This international division of intellectual labour, "in which the setting of theoretical agendas and methodological standards are the prerogative of [...] societies and institutions [...] located in the economically privileged regions of the world" (Nandy 1983: 116; see also Ahmad 1992), has been criticised from various quarters. Referring to knowledge produced in Western universities, Weiler observes that " $[\mathrm{t}]$ he transnational division of labor between center and periphery functions in both realms: the international knowledge order is as much dominated by the knowledge institutions and traditions of the West as the international development order is dominated by the powerful center of donor and investor agencies" (Weiler 2009: 8). Even Western knowledge formations like Postcolonial Studies for various Indian critics have done violence to cultural traditions that for centuries had given meaning to Indian peoples (see Prakesh 1999; Spivak 1988; Chatterjee 1986; Nandy 1983). Concepts of self-description and analysis like 'postcoloniality', 'subalternity', 'indigeneity', 'religion', 'philosophy', and even the concept of the 'concept' have come under scrutiny as they converge in the devaluation of non-Western knowledge paradigms as mythical, religious, or spiritual in character, and thereby affirm the Western "claim to superior, objective, and universal knowledge” (Nanda 2003: 153; see also Devy et al. 2014; Chakrabarty 2000). As Zizek (2009) points out, the universal validity claims of Western thinking are not restricted to these norms and values, but include the individuals themselves: “[I]ndividuals relate to themselves as 'universal', they participate in the universal dimension directly, by-passing their particular social position.” In this context, historiography as a central Western strategy of (selectively) ordering the 
past (see Abeysekara 2013: 506) has received particular attention because of its conceptual allegiance with the equally problematic semantic fields of 'development' and 'modernity' (see Chakrabarty 2000; Lal 2003). Weiler expounds:

\begin{abstract}
Institutionalized efforts at development, whether they originate at the national or international levels, have established their own hierarchies of knowledge where certain kinds of knowledge claim higher standing and greater influence over other kinds. Knowledge about development that is validated internationally, preferably through publications in North American or European journals, commands a higher status than work published in the developing regions of the world, often regardless of how relevant [...] it may be to [...] those regions. Similarly, higher status is conferred upon work that conforms to the evidentiary and analytical standards of Western [...] sciences. (Weiler 2009: 7)
\end{abstract}

These hierarchies are implemented by "power differentials [which] fundamentally determine how knowledge is perceived, whose knowledge matters, and the ensuing effectiveness of policies on which it is based" (Weiler 2009: 7). The 'Digital Revolution' is one such power differential, which spreads a "narrative [...] that charts the [...] superiority of Western science throughout the world" (Ratté 2012: 17) and defines knowledge societies with reference to norms of Western knowledge production. In this situation, the UNESCO World Report on Knowledge rhetorically asks: "Do we have to endorse the hegemony of the techno-scientific model in defining legitimate and productive knowledge?" (2005: 5)

To redress the overwriting of the "diversity of cognitive cultures" (UNESCO 2005: 148) by Western knowledge paradigms, writers, critics and activists in former colonies like First Nation writer Jo-Ann Episkenew (2009) in Canada, Dipesh Chakrabarty (2000), Ashis Nandy (1983, 2000) and Vinay Lal (Lal/Nandy 2005) in India, Frantz Fanon (1980 [1952]) and Ngũgĩ wa Thiong’o (1986) in Africa, and movements like the Australian Aboriginal Progressive Association (AAPA) - to name a few -, see it as imperative to 'decolonise the minds' (Ngũgĩ wa Thiong'o), to 'de-educate' (Episkenew) and thus to end the 'cultural amnesia' (see Devy 1992) imposed by Western colonisation and epistemological hegemony. More specifically, Ashis Nandy suggests that universities "begin to act as sources of scepticism toward the victorious systems of knowledge, and as the means of recovering and transmitting knowledge that has been cornered, marginalized or even defeated" (1983: 118). From this perspective, a universal condition for a knowledge formation to be counted as 'valid knowledge' lies in its authority to organise the communal co-existence of humans and their natural environment. In this respect, for "retaining a valid concept of the universal [one has to] incorporat[e] non-European, anti-imperialist and socialist histories" (Mukherjee 2011: 180).

However, Ganesh Devy in his contribution to this volume illustrates with reference to India that such 'knowledge wars' are not restricted to combats between East and West or North and South - depending on perspective -, but that intra-national political issues of classes, castes and tribes are also delivered in fiercely evaluative 
discourses, in which culturally specific knowledge traditions like Sanskrit as well as Western paradigms are pitted against indigenous archives and practices of knowledge - and vice versa.

The essays in Part I of this volume - "Competing Knowledges on a Global Scale" - analyse the conflict between competing knowledge formations in colonial and postcolonial power constellations in India, in seventeenth century Brazil, and in a confrontation of Western with First Nations knowledge in present day North America. However, the entanglement of knowledge and power is just as intricate, though often more subtle than in postcolonial constellations, if we restrict our view to the competition of various disciplines in Western academia for public recognition.

\subsection{Legitimising Knowledge - Disciplining Knowledge}

In recent years, discussions in the Sociology of Knowledge have focussed on the aspect of legitimation in procedures of knowledge production (see Schützeichel 2007: "Soziale Epistemologie”, 291). The efforts to justify the validity claims of specific knowledge formations are motivated to a large extent intrinsically by the search for - their respective - truth, but they are also compelled by the necessity to receive public acknowledgement in order to acquire political and social bearing and - possibly - access to funding and institutional forms of dissemination like patrons, courts, schools and universities. The strategies of legitimising knowledge vary widely in different historical, cultural and disciplinary contexts. Possible legitimatory reference points are individual experience, institutionalised authorities, cultural traditions, pragmatic considerations, detailed norms of scientificity, historically specific concepts of truth, ethical considerations, or - as the essay of Sabine Maasen in this volume illustrates - the present-day keywords 'innovation', 'social relevance', and 'excellence'.

With view to Western sciences, the historicisation of knowledge paradigms exposes that ultimately the differentiation of disciplines is intricately bound up with their distinct legitimatory strategies, that is with the construction of 'truth' and 'authority' in their specific realms of knowledge (see Rößler 2012; Daston/Gallison 2007; Daston 1991; Shapin 1994). These negotiations about the normative conditions of what counts as knowledge generate historically and culturally diverse hierarchies of knowledges associated with their relevance, cultural authority, reputation and reliability, and thus demarcate continually shifting and fuzzy boundaries between what is acknowledged as legitimate and what is illegitimate knowledge (see Bourdieu 1989). The fuzziness stems from the fact that the distinctions are implemented by normative definitions of the 'knowledge horizon' (Erkenntnishorizont), which marks a border to non-knowledge or the unthinkable, and classifies what counts as knowledge proper and what can be known under which conditions. In this way, the 'horizon' ultimately disciplines the legitimatory procedures in the respective knowledge formation, and 
thus discursively installs the conditions for the possibility of knowledge (see Adler 2013: 26). In Foucault's classic definition,

a discipline is not the sum of all that can be truthfully said about something; it is not even the set of all that can be accepted about the same data in virtue of some principle of coherence and systematicity. [...] Within its own limits, each discipline recognises true and false propositions, but it pushes back a whole teratology of knowledge beyond its margins. The exterior of a science is both more and less populated than is often believed: [...] perhaps [in the exterior] there are no errors in the strict sense, for error can only arise and be decided inside a definite practice; on the other hand, there are monsters on the prowl whose form changes with the history of knowledge. (Foucault 1981: 59-60)

Similarly, Grenfell and James (2004: 510) with regard to the 'Bourdieusian field' of educational research expound: "Any field is also 'bounded', and there is that which is included in it and that which is excluded. [...] [I]t is constituted by all that is methodologically possible within it; in other words, its topography amounts to the range of research activity and the principles that guide it."

In Europe, legitimising self-descriptions of specific knowledge formations abound already in the Early Modern Period, when religious dogmas were challenged by the 'New Sciences', the precursors of the natural sciences (see Nate 2009). Ironically, their explicit claims to rationality and empirical observation as legitimatory reference points quite often were at odds with the rhetorical means to justify their methodology: Thus Roger Bacon, a founding father of the 'New Sciences', in his Instauratio Magna (1620) defended the new knowledge paradigm with extensive references to the Bible and Greek mythology (see Nate 2009: 151-170; Nate 2018: 45-63, esp. 46-49).

Historically, the central legitimatory strategy consisted in proving the truth - or validity - of one's statements. However, Hans Blumenberg (1993: 32) traces significant changes regarding concepts of truth from Plato's alignment of truthful knowledge with "Being as the self-representation of beings [perceived by] the inactive, calm contemplation of theōria", to the legitimation of validity claims by reference to their methodological place in a normative knowledge system like empiricism. Additionally, already in the Early Modern Period, when the latter strategy was established by the 'New Sciences', 'proving' something was a contested practice that bred fierce conflicts about degrees of trust, the boundaries between scholarly disciplines and the purview of official institutions (see Nate 2009: esp. 11-44, 65-170). Considering this historical and conceptual 'unreliability of concepts of reliability' (see Hörisch 2007: 10), attempts to ascertain 'true knowledge' against 'fake news' today cannot revert to the suggestion of some innate truth of scientific or any other kind of knowledge, but have to analyse, differentiate and expose the genesis - and validity - of legitimatory practices in different knowledge formations instead.

Part II of this volume - "Disciplinary Negotiations" - illustrates cases of current disciplinary differentiations by specific strategies of legitimation in various academic 
fields, and shows the limits - and the necessity - of such disciplinary boundary work in present-day knowledge societies.

\section{What is Knowledge Research?}

Knowledge Research responds to the growing scientification of contemporary knowledge societies and the resulting dissolution of former - supposedly clear - differentiations between different kinds of knowledge formations like scientific and everyday knowledge. In consequence, “[t]he aim of systematic and reflective knowledge research is to elucidate the peculiar profiles of knowledge forms as well as their interplay" (Abel 2012: 3), as Abel states in the two volume anthology Rethinking Epistemology (2011/12). The interplay of various knowledge forms is understood as an irreducible plurality that exceeds normative ideas of mutual exclusion or hierarchisation. With this premise, Knowledge Research focuses on interdisciplinary, interphilosophical and intersocietal problems beyond disciplinary limitations in order to develop pragmatic heuristics that are "capable of contributing to our orientation in everyday life, in the sciences, and in the arts. Indeed, helping to orient us in this manner constitutes a great deal of the humane significance of systematic and reflective knowledge research." (ibid.: 12) In contrast, traditional epistemologies neglect the "social, cultural, and mental dimension of scientific knowledge" (Sandkühler 2014: 68; my translation) ${ }^{1}$ as well as non-scientific modes of knowing and of being in the world (cf. Abel 2012: 13-14). Accordingly, Wolfgang Detel illustrates that the Platonic definition of knowledge as 'true justified belief' is too narrow a concept to grasp the complex interrelatedness of modes and methodologies of knowledge formation with epistemological, institutional, political and economic power constellations.

The model of 'belief' and 'justification' Detel refers to was established in Plato's Theaetetus by the character of Socrates, who points out that "true belief" cannot be considered knowledge unless it is "justified" (Plato 1961: 254-255). However, for centuries each term of this definition, namely 'justification', 'truth' and 'belief', has been contested. Not surprisingly, the debates were mostly conducted by privileged and male members of the respective societies and focussed on knowledge formations entrenched in authoritative social discourses and institutions. This tradition is reflected in present-day Knowledge Research insofar as it seems to concentrate on the knowledge of the natural sciences, thereby even in their critique affirming "the hegemony of the techno-scientific model in defining legitimate and productive knowledge" (UNESO 2005: 5).

1 "soziale und kultur- bzw. mentaliätsgeschichtliche Dimension wissenschaftlicher Erkenntnis". 
Yet while traditional knowledge definitions focus on propositional and conceptual thought, rationality and systematicity, ${ }^{2}$ Knowledge Research tends to favour constructivist models, incorporates non-binary epistemological attitudes, relativity and plurality, and includes knowledge mediated by non-rational ways of cognition such as emotions and beliefs in their studies: "It is an important aspect of the broad sense of basic, factical knowledge that this concept is deeply, firmly anchored in our everyday language, our life-world, and our ordinary practices.” (Abel 2012: 22) Embracing such a broad concept of knowledge that does not discriminate against non-linguistic, non-propositional and implicit knowledge, systematic Knowledge Research "formulates [...] the ways in which knowledge forms interpenetrate perceptual, conceptual, and enactive processes in speech, thought, and action" (ibid.: 6). Such a systematic Knowledge Research in Abel's view precedes classical epistemology from a methodological perspective, and transcends the "exclusive dominance of the model of 'belief' and 'justification'” (ibid.: 23) as normative conditions for true knowledge.

The following will at first trace a few historical precursors of Knowledge Research concerning the natural sciences, before turning to some reflections on aesthetic knowledge.

\subsection{From the Ingenious Individual to Knowledge Cultures}

Till well into the twentieth century, discussions about the production and definition of legitimate knowledge rested on the premise of a 'Cartesian epistemology' and assumed that agency in scientific knowledge production rested entirely with the individual scientist's (decidedly gendered) intellectual potential in command of adequate methodological procedures. Knowledge was "the exclusive domain of tight circles of wise men and the initiated few” (UNESCO 2005: 17), and epistemic dynamics were bound to their intellectual potency.

Only in 1935, the Polish physician Ludwik Fleck with his foundational Entstehung und Entwicklung einer wissenschaftlichen Tatsache - which went virtually unnoticed till Kuhn mentioned him nearly thirty years later in The Structure of Scientific Revolutions (1962) -, introduced the social dimension of scientific knowledge production, which has become the central focus of any Sociology of Knowledge, Sociology of Science, and Social Epistemology since then. ${ }^{3}$ Fleck, in his observations on the discovery of syphilis, comes to the conclusion that scientific knowledge production cannot be conceptualised adequately in a model comprising only the subject and the object of investigation without taking the respective state of the art and the concomi-

2 For an example, see in this volume Hoyningen-Huene, "The Heart of Science: Systematicity.”

3 Hubert Knoblauch in his essay of this volume holds that in contradistinction to the Sociology of Knowledge, the Philosophy of Science is still based on a Cartesian epistemology. For a contextualising approach to knowledge definitions from a Philosophy of Science view see Brendel/Gähde 2016. 
tant 'thought collectives' (Denkkollektive) into consideration. According to him, each collective maintains a specific thought style (Denkstil), which preconditions the perceptions and concepts of the respective members (Denkzwang). However, as the individual scientist is part of several such thought collectives, each disciplinary thinking style will be changed by extrinsic influences. This model denies any exclusivist position to the individual researcher as well as to scientific knowledge in comparison to non-scientific thought collectives; indeed, for Fleck the 'traffic of ideas' (Gedankenverkehr) between various thought collectives is the essential task of the sciences (see Schützeichel 2007: “Soziologie des wissenschaftlichen Wissens”, 308-309). The so-called laboratory studies, explicated most prominently in Bruno Latour's ActorNetwork-Theory, add another narcissistic mortification to the myth of the individual scientific genius by attributing foundational agency to trans-scientific networks of personal, natural, and material phenomena, which are indispensible for the production, dissemination, acknowledgement, and establishment of scientific findings as legitimate knowledge (see Latour 1988 [1984]).

In constructivist and contextualising models of scientific knowledge production following in the wake of Fleck's conception, changes of epistemic practices and breaks with traditional semantics of 'knowledge', 'rationality', or 'truth' are seen in close connection with historical conditions like the function of rhetorics in the cities of antiquity, legitimatory strategies of scientists within the patronage system, the debates about experimentation versus metaphysical discourse as proper philosophical or scientific methodology in the Early Modern Period (see Detel 2014), and strategies of funding, institutionalising and thereby steering the production and dissemination of knowledge in present-day educational and science policies.

With knowledge as the product not primarily of individual ingenuity, but of social and material conditions, it has to be relocated as a part of cultural and intersubjective processes. The term 'knowledge cultures' points towards this interrelation of 'knowledge' and 'culture': Knowledge cultures shape the generation of knowledge, which, in turn, works towards 'justification' or 'truth' within the respective cultural and epistemological framework. It is crucial to understand that 'knowledge cultures' are not neatly defined areas of human interaction, but highly complex "relationships inside and in between hybrid cultures and forms of knowledge" (Sandkühler 2014: 62; my translation $)^{4}$ that constitute the conditions for difference and dedifferentiation. The plural of 'knowledge cultures' implies the dynamics of these processes throughout cultures, while simultaneously rejecting claims to hegemony. In this way, knowledge cultures function not only as conditions for acknowledgement and affirmation, but ultimately as a framework for any kind of access to the world: "Cultures of knowledge are conditions of possibility and limits of cognition, according to the degree of participation in or exclusion from knowledge.” (Sandkühler 2012: 181) More specifically, Wolfgang Detel, taking up the tradition of theorists like Ludwik Fleck,

4 "Verhältnisse innerhalb und zwischen hybriden Kulturen und Wissensformen". 
argues for a concept of knowledge cultures as "cultures [...] consist[ing] of practices, which are based on a few premises and are related to mechanisms of tradition" (Detel 2014: 73; my translation) $)^{5}$, and which acknowledge both propositional and practical knowledge. With this model, each society is a knowledge society, a view which is also endorsed by the UNESCO World Report on Knowledge: "Does the aim of building knowledge societies make any sense when history and anthropology teach us that since ancient times, all societies have probably been, each in its own way, knowledge societies?" (UNESCO 2005: 17) However, characterising Western societies as specific knowledge societies highlights their change from societies of industrial production to societies, where a specific class producing knowledge is growing rapidly, and where - starting in the US after WWII -, the value of formal education as 'symbolic capital' (Bourdieu) is rising exponentially in all professions.

Politics, according to Rudolf Stichweh, occupy a very special place in this social and epistemological landscape of knowledge cultures, because political decisionmakers - in the absence of any genuine political knowledge culture - have to rely entirely on the import of expert knowledge. The essays in Part III - "Competing Knowledges in Politics" - analyse and illustrate, how politics in Western knowledge societies access the variety of competing knowledge cultures in order to replace the intra-systematically beneficial 'ignorance at the center of the system' by the knowledge of expert knowledge cultures, and thus respond flexibly to the challenges of social dynamics.

\subsection{New Epistemologies for Scientific Research?}

The shift of perspective from 'truth' or 'reality' as legitimatory yardsticks for scientific knowledge to social and material conditions governing scientific knowledge production necessitates a revision of epistemological tenets. In consequence, Abel (see 2012: 27) argues in favour of a modified epistemology that re-anchors knowledge in the life-world. For him, epistemology should no longer be a meta- or intratheoretical reflection, but incorporate the facticity of the I-We-World triangle, because a "3D-epistemology" would allow for a non-dualistic semiotic and interpretative theory of epistemic objects that does not imply the primacy of one particular knowledge form over another. Such a model would have to include a maximum of the factors at play in the formation of knowledge (see Sandkühler 2014: 70), while still keeping in mind the discrimination that all talk about knowledge necessarily depends upon (see Abel 2012: 31).

Accordingly, in Social Epistemology knowledge becomes a communal phenomenon that is anchored in and that simultaneously creates a collective reality based on

5 "dass Kulturen im allgemeinsten Sinne aus Praktiken bestehen, die auf einigen Hintergrundüberzeugungen beruhen und mit Mechanismen der Tradierung verknüpft sind.” 
specific ways of thinking (Ludwik Fleck's 'Denkstile'). Yet such a notion of epistemology has consequences for the authority and the methodologies not only of the sciences, but of academic research in general. In fact, the perspective on subjectivity and relationality resulting from the revised understanding of 'knowledge' in the context of 'knowledge cultures' proves to be highly problematic for conventional scientific practice, since it turns the causality of rational reasoning upside down:

Knowledge cultures form the possible conditions for the possibility of cognitive procedures and epistemic results. They form the basis for the perception of situations, for the evaluation of situations as facts, for the selective cognitive grasp of reality, for the acceptance of rules and norms, for the understanding, interpretation, explanation, and description, for the use and non-use of instruments for knowledge acquisition (for example before and after an invention like the telescope and the microscope), and also for systems of observation and experiment. (Sandkühler 2014: 65; my translation $)^{6}$

Seemingly self-evident viewpoints or assumptions are reframed as the result of methodological and theoretical choices that are based on an "epistemic profile" (Sandkühler 2012: 175). Thus, knowledge is no longer perceived as the result of solely mental efforts at grasping and representing reality, but as a context-based phenomenon intrinsically linked to social, economic and political conditions as well as to preceding sentences, to emotions and to an entire habitus. As a result, statements appear as 'artefacts' "charged with conditions of cultural knowledge norms and social practices, epistemological and practical needs and interests, as well as propositional attitudes of opinion, belief, conviction, desire and apprehension" (Sandkühler 2014: 63; my translation). ${ }^{7}$ With relationality instead of rationality at the core of scientific knowledge production, Sandkühler proposes “to lay one's cards on the table on behalf of the clarity and truthfulness of reasoning. The arguments for which validity is claimed should be dated and provided with one's own signature - the signature of a choice." (Sandkühler 2012: 175)

6 "Wissenskulturen sind mögliche Bedingungen der Möglichkeit kognitiver Prozesse und epistemischer Resultate. Sie sind Gründe für die Wahrnehmung von Sachverhalten, für die Bewertung von Sachverhalten als Tatsachen, für den selektiven kognitiven Zugriff auf die Wirklichkeit, für die Akzeptanz von Regeln und Normen, für das Verstehen und Interpretieren, Erklären und Beschreiben, für den Gebrauch oder Nichtgebrauch von Instrumenten des Wissenserwerbs (etwa vor und nach der Erfindung z.B. von Teleskop und Mikroskop) und auch für Beobachtungs- und Experimentalsysteme.” 7 "[...] geladen mit wissenskulturellen und praktisch-sozialen Voraussetzungen, epistemischen und praktischen Bedürfnissen und Interessen sowie mit propositionalen Einstellungen des Meinens, Glaubens und Überzeugtseins, des Wünschens und Befürchtens.” 


\subsection{Aesthetics}

One branch of Knowledge Research asks after the place accorded to experiential phenomena like aesthetic perception as a mode of knowledge production, in contradistinction to the exclusive position rendered to rationality, propositionality and noesis in traditional epistemological models. A widespread denigration of humanistic knowledge in general and aesthetic knowledge in particular makes the UNESCO World Report on Knowledge remind its readers: "Useful knowledge is not simply knowledge that can be immediately turned into profit in a knowledge economy - 'humanist' and 'scientific' knowledge each obey different information-use strategies.” (2005: 19)

The subordination of aesthetic knowledge under logical knowledge has a long history. As late as 1750, the German philosopher Alexander Gottlieb Baumgarten in his Aesthetica finally declared aesthetics as the 'younger sister' of logic (see Baumgarten 2007 [1750]: Prolegomena § 13) and - according to an ironic remark of Kant thereby "hoped of bringing the critical estimation of the beautiful under principles of reason, and elevating its rules to a science” (Kant 1998 [1781/1787]: A21/B35; see also McQuillan 2015). Sensual perception (aisthesis) had traditionally been considered only as the physiologically limited and therefore faulty basis of conceptual knowledge (noesis), and consequently it had to be transcended. Against this conviction Baumgarten aimed to establish aesthetics as a new epistemology in its own right and to place it on a par with logics (see Mirbach 2007: esp. XXVI).

Hans Adler (2013), referring back to Baumgarten, similarly argues against a hierarchisation of aisthesis and noesis and ascribes unique dimensions of truth to both aesthetic and logical forms of knowledge, bound to their specific - equally valuable and equally limited - 'horizon'. Thus, as Dieter Mersch in his reflections on aesthetics in Epistemologien des Ästhetischen (Mersch 2015) spells out, the aesthetic episteme in contradistinction to the natural sciences does not aim at generalisation, repeatability, or universality, but at re-establishing the significance of the singular (see also Mersch 2013: 8). More generally, Mersch deconstructs the claim that knowledge proper per definitionem is bound to propositionality, and that means to linguistic statements and standards of rationality. ${ }^{8}$ Mersch refutes this seemingly clear-cut differentiation between propositionality and non-propositionality by exposing how the non-propositional dimension is continuously excluded from the propositional statement in order to enforce the latter's claim to 'truth'. The result, in Adler's terms, is a fragile idyll with unstable and permeable boundaries, in which the respective knowledge formation acquires only the semblance of stability as "the gnoseological conditio humana"

\footnotetext{
8 "In Bezug auf die Wissenschaften erweisen sich folglich Propositionen als die eigentlichen Bedeutungsträger, die deren Wahrheit oder Falschheit als binäres Schema allererst austragen. Als Urteile verfahren sie entweder bejahend/zuschreibend oder verneinend/absprechend, so jedoch, dass sie als ihren Rationalitätsausweis bereits die ganze klassische Logik mit ihren Prinzipien der Identität, des Widerspruchs und des ausgeschlossenen Dritten voraussetzen.” (Mersch 2015: 2)
} 
(Adler 2013: 42; my translation). Hans-Heinrich Trute in this volume analyses and very graphically illustrates strategies to construct such a 'semblance of stability' with regard to legal knowledge.

In light of these premises, Mersch (see 2015: 6-7) sees a twofold potential of aesthetic knowledge: On the one hand, non-propositional knowledge can subvert propositional discourses as the 'Other' of rational insight, and on the other hand, it can engender thinking beyond the binaries of propositional thought, because - different from a rational argument -, an aesthetic way of thinking works by means of "de-synthesis", where contrasts and correlations, continuities and contingencies are not necessarily submitted to harmonising attempts at producing a stable 'message'. The English Romantic poet John Keats called this ability to bear unresolved tensions the 'negative capability', "when man is capable of being in uncertainties, Mysteries, doubts, without any irritable reaching after fact and reason” (1958 [1817]: I. 193). Karin Gludovatz in this volume maps out such an aesthetic way of communication through unresolved juxtapositions of aesthetic and political knowledge formations in the paintings of a seventeenth-century colony in South America by the Dutch painter Albert Eckhout.

Literature as an important medium of aesthetic knowledge production and dissemination exemplifies these claims to a particular aesthetic knowledge production very strikingly. Gess and Janßen situate literature in the epistemological landscapes of various academic disciplines, and come to the conclusion that literary texts expose "a specific sensibility for the arcane, excluded, discarded or for the unacknowledged questions, also for whatever is not known” (2014: 6; my translation). ${ }^{9}$ Thus, literature includes undecidability, disagreement and incompatibility, and in large parts can be considered "a 'dissident archive' which [...] deserves to be taken seriously for providing a range of alternative perspectives to everyday and to disciplinary bodies of knowledge" (Kley 2018: 10). These perspectives are made plausible by literary devices like plotline and formal traits, which dramatise and negotiate the potential as well as the limits of individual, relatively 'closed' knowledge formations. In an additional loop of self-reflexive critique, fictional texts like artists' novels even expose the strategies of literary knowledge production and thereby contextualise and subtly undermine any suggestion of complete and unmediated understanding, or any universal validity claims (see Horatschek 2008: 4-7).

Despite - or perhaps because of - this critical self-reflection, and notwithstanding its "enthusiastically relaxed attitude towards categories like accuracy, adequacy, reality" (my translation), ${ }^{10}$ 'the knowledge of literature' (see the title of Hörisch 2007) offers analyses of social and individual issues, which can easily compete with the sig-

9 “[...] eine besondere Sensibilität für das Arkane, Ausgeschlossene, Verworfene oder für das noch Unbeantwortete und Fragliche, also für das eigentlich nicht Gewusste”.

10 "[ein] enthusiastisch gelassenes Verhältnis zu Kategorien wie Richtigkeit, Sachangemessenheit, Realität”. 
nificance of any findings presented by so called hardcore-science (see Hörisch 2007: 35). Topics like climate change, biodiversity, energy supply, rational-choice-models and consciousness studies imply questions which cannot be addressed comprehensively with the knowledge produced by the natural sciences alone, but need models which conceptualise the situation of "the socially situated human being in all its paradoxical implications in [...] the quietly pervasive powers of natural, material, and social environments. [...] Literary writing stages [such] plausible, interesting, and productive - rather than scientifically true - insights" (Kley 2018: 11). Finally, cognitive and reception oriented approaches to literature agree that the narrative competence fostered by reading literature produces 'social cognition', which "broadens readers' [sic] horizon by simulating the thoughts and feelings of others [and] presents patterns which readers can apply in their daily lives; they enable readers to become skilled at understanding social relations and personality traits" and thereby "induce readers to question and even discard stereotypes and clichés” (Nünning 2014: 47, 172).

All of the above reflections on literary knowledge respond to the so-called theoretical turn in the humanities and thus presuppose a historically specific concept of the knowledge of literature. Despite significant differences in terms of philosophical premises and analytical range, many theories of this 'turn' fundamentally criticise hermeneutics - the science of textual understanding and the foundational methodology of the humanities - for their 'rage for understanding' (see Hörisch 1988) and - in a key phrase of Michel Foucault - 'the will to know' (Foucault 2013). The attempts to consensually establish a unified meaning in the respective - literary - thought collective are understood as indications of the will to gain control over the (textual) world by reductively assimilating the plurality of the (textual) world to the methodological, theoretical, or ideological categories at hand. Partly in continuation of Foucault's thinking and additionally inspired by deconstructive, post-structural and postmodern critiques from philosophical and psychoanalytical quarters of mostly French origin, a host of theories demanded an 'ethics of reading' (see Miller 1987) decidedly directed 'against closure' and in favour of ambiguity, undecidability, equivocality, gaps, différance, and the proliferation of liquefied meanings. These debates, which restructured key concepts of literary studies irrevocably till today, dominated discussions and methodological procedures in the humanities during the last half of the twentieth century to such an extent that in a postmodern novel - a genre notorious for self-reflexive comments on the theory industry -, a professor of English Literature regretfully remarks: "Coherence and closure are deep human desires that are presently unfashionable.” (Byatt 1991: 422) 


\section{From Knowledge as 'Justified True Belief' to Believed Knowledges}

An understanding of knowledge as the result of socially embedded practices requires the reassessment of the very concept of (linguistic) representation, namely a changed attention of the analytical perspective from a reality-representing function of knowledge to a reality-creating one. According to Sandkühler, an epistemology that takes knowledge cultures into account does not ask to which extent human knowledge represents a world of things, but it focuses on the transformation of phenomenal reality into knowledge formations attuned to a human scale and conditioned by epistemic and cultural conditions: "[T]he crucial question of epistemological pluralism and internal realism is not how our knowledge depicts reality according to the measure of things, but how the phenomenal reality emerges within knowledge, humanly speaking.” (Sandkühler 2012: 174; also Sandkühler 2014: 59-65) The general and public acceptance of the justifications for these knowledge worlds for Sandkühler - just like for Socrates in Plato's Theaetetus - ultimately rests on beliefs, which, however, are now perceived as justification-transcendent and immune to falsification, even though they may be based on weak foundations like experience or authority. The legitimation of specific knowledge formations is only accomplished within such a belief system and is "the result of the (basic) belief that a whole belief system is coherent and justified with the entirety of its self-evidences" (Sandkühler 2012: 189). By reinterpreting self-evidence as believed certainty and (propositional) knowledge as a "belief of having knowledge” (Sandkühler 2012: 185), beliefs are perceived as an intrinsic aspect of human existence that works to "minimize the requirements for the justification of knowledge and action" (Sandkühler 2012: 188), and, thus, protects individuals, groups and cultures against criticism.

The hazard inherent in this model of legitimating validity claims by ultimately referring to beliefs lies in the danger to uncritically "mark the limits of intolerance" (Sandkühler 2012: 185); its potential lies in its ability to provide a non-hierarchical 'epistemic home' for many knowledge forms, because legitimation here rests on coherence, and thereby avoids any universal and absolutistic claims to knowledge and truth. Instead, this revised understanding binds knowledge to social acknowledgement without abolishing the significance of its truth, because "beliefs which are recognized in accordance with rules, can be communicated and publicly justified, are understandable for third parties and which do not abuse the norms of human rights can claim acknowledgement. They are 'true' beliefs for individuals as epistemic subjects and for sign and meaning communities. They are knowledge humanly speaking.” (Sandkühler 2012: 190-191) Thus, normative ideas of 'truth' must not be dropped entirely. Rather, they are still fundamental within the specific concepts of knowledge, yet should raise more modest validity claims - namely as true in the context of a specific belief system. Albert Meier's essay addresses the conflict of two such meaning 
communities in the US, namely the knowledge of academic historians and the Cheyenne River Sioux about the origin of First Nations Peoples on the continent.

With this approach, 'knowledge' can only be defined according to the criteria held by the respective thought collectives and disciplines themselves (see Schützeichel 2007: “Max Scheler”, 63), necessitating a dialogue not only between disciplines, but also between science and the general public. Conceptualised as a form of collective and participatory knowledge production, scientific knowledge production in this model would function as "the best means of providing a training in interdisciplinary thinking, since it brings individuals face to face with different forms of knowledge", generating "new rules governing the scientific method, that are valid outside the laboratory and no longer simply within it" (UNESCO 2005: 129, 120). However, Sabine Maasen in her essay succinctly illustrates the inherent problems of such expectations for the actual practice of scientific research in Germany, and Konrad Ott in a case study shows the complexity of participatory knowledge generation concerning the deposit of radioactive waste.

On a grander scale, such revised notions of knowledge aim at a pluralism of knowledge forms and cultural diversity that makes humans "feel at home in a changing world". Ultimately, the encouragement of knowledge pluralism and diversity feeds the vision of "nurturing the creativity of emerging knowledge societies. Such a prospect fulfils not only an abstract ethical imperative, it above all aims to raise in each society an awareness of the wealth of the forms of knowledge and capacities it possesses, in order to increase their value and take advantage of what they have to offer." (UNESCO 2005: 17, 18) Scientific research as well as general knowledge production conducted according to these - as yet utopian - tenets might indeed contribute to the development of knowledge societies in a way that emphasises the human and humane foundations of knowledge and that "opens the way to humanization of the process of globalization. [...] To remain human and liveable, knowledge societies will have to be societies of shared knowledge. The plural here sanctions the need for an accepted diversity.” (UNESCO 2005: 27, 5)

\section{The Essays}

\section{Part I: Competing Knowledges on a Global Scale}

Ganesh Devy, in his essay Competing Knowledges: An Indian Perspective, first offers an overview of the traditions and politics of knowledge production and distribution in India. He starts with the observation that a comparative study of Indian and Western knowledge paradigms is difficult, as the meanings of terms like 'logos' and 'philosophy' and their translations as vidya and darshan are anchored semantically in different hermeneutic horizons, which moreover changed in the course of centuries. 
Another problem arises from the fact that in the nineteenth century Western scholars like Max Müller as well as the native literary class in India held the colonial attitude that European, specifically British, education was far superior to Indian knowledge traditions. As a consequence, there is a pervasive amnesia in Indian scholarly circles about their Indian knowledge traditions today, and a lack of significant contributions to knowledge production on a global scale. In addition to the impact of colonialism, castism has denied large parts of society access to education in India.

To address the question of what is understood as knowledge in Indian traditions, Devy differentiates between knowledge as noun and as verb, and expounds that generally Indian "pedagogies for the inter-generational transmission of wisdom - what we call 'education' -, and the typologies of what was known or worth knowing what we call 'disciplines'-, were oriented towards quickening the process of knowing rather than consolidating the object called knowledge" (41). More specifically, Devy outlines knowledge definitions of the Upanishads, Buddha, and Abhinavagupta, in the Natyashastra with its minute taxonomies of aesthetic experience (rasas) and emotive states, and in the Tamil Tolkapiyyu, before he traces significant changes of knowledge concepts in the wake of shifts from Tamil, Pali and Sanskrit as the traditional languages of classical knowledge transaction to modern Indian languages such as the modern Tamil, Malayalam, Telugu, and Kannada, to name but a few. Yet his focus lies on the knowledge of non-canonised oral traditions of the indigenous communities (adivasis) and the 'untouchables' (shudra). In contrast with European traditions aimed at universal knowledge, Indian knowledge traditions, tribal as well as canonical, insisted on individual intuition as the fountainhead of knowledge. In this tradition, 'true knowledge' had to be legitimised by personal superiors, not by objective criteria. This way of knowledge transmission meant a considerable disadvantage when confronted with rapid 'modernisation' in the colonial era.

The second part of Devy's essay turns to culturally specific strategies of 'storing' knowledge. In contradistinction to Europe, where from the sixteenth century onwards scholars were working at "systematising and representing ideas in terms of what came to be accepted as 'universal science'” (45), in India the largely oral traditions of knowledge production, transmission and preservation together with castist exclusions from literacy meant a deepening of social segregation regarding knowledge preservation. This process was further intensified with the advent of printing technologies from the beginning of the nineteenth century onwards, and ultimately created a "deeply divided memory field", which eludes any overarching classificatory scheme like a "unified grid tied firmly to 'all memory' - as it had happened a couple of centuries ago in Europe” (47). Instead, European binary differentiations, for example between literature and folk-literature, architecture and vernacular, and languages and dialect, were transferred to all spheres of life in India, perpetuating and "internalising a pervasive cultural amnesia" (38). At the same time in Europe, memory was first denigrated by the Romantics, then reinstated by Freud, Hegel, and Marx "in the structured and narrated form of history” (48), and finally 'outsourced' to digital media. With this 
"alienation of memory from humans" (48), according to Devy, the brain may develop 'post-memory knowledge' based on images and unconstrained by grammatical structures or tenses. He closes his essay envisioning future comparative studies of Indian and Western knowledge traditions based on further evolutionary developments in man's cognitive capabilities.

Karin Gludovatz, in her essay Fruits of heAven: Artistic Knowledge AND the AESTHETIC ORDER OF THE ‘NeW WORLD' IN ALBERT ECKHOUT's STILl LifES, explores "the transformation of traditional artists' knowledge in conflict with individual experience of alterity, framed by the conditions of colonialism" (51). Her example is the seventeenth century painter Albert Eckhout, when he was confronted with the Brazilian landscape and peoples. The initiative of his patron Johan Maurits von Nassau-Siegen - inspired by Enlightenment ideas - to produce documents about the territory and its peoples with universal validity claims for the knowledge thus obtained was unique in the early colonial history of the Americas, and Eckhout's still lifes would prove formative for European knowledge about Brazil for the next 200 years. However, this knowledge was also meant "to justify Dutch domination in South America in competition with the aspirations of the Spanish and Portuguese [...], while in turn that colonial policy also shaped that very knowledge" (53). The still lifes deviate from the genre conventions by arranging the fruits and vegetables not in an interior, but outside and seen from below, with the fruits and vegetables towering above the observer and opening the view into the sky. According to Gludovatz, the pictures would develop their own discursive power depending on whether the recipients - all of them coded by the epistemological horizon of colonialism - were on site, or in Europe. While the former would perceive them as an ideal of European rule by order and classification, for the latter they would function as a legitimation of political hegemony and serve as a testimony of empirical knowledge production by an eyewitness. The handling of space in these pictures on the one hand responds to the widening horizon of the world in European cultures, but on the other hand it is bounded by a sky from Dutch landscape paintings and thus by adherence to the "artistic genealogy in stylistic terms" (61). The very selection of fruits from all over the world gives evidence of "the mobility of European powers motivated by colonial expansions and long distance trade [...], balanced out by artistic principles of composition" (63). However, for Gludovatz, the retrospective classification of Eckhout's still lifes as indications of scientific interests is questionable. If there were any, they would have been bound to "the backdrop of [Eckhout's] own culture and artistic techniques, and to the structure of colonial domination and power that Eckhout is implicated in." (65)

Albert Meier, in his article In SCIEnCE We Trust: Überlegungen ZUM WisSEn DeR Wissenschaften (In SCIENCE We TRUST: Reflections on the KNOWLEDGE OF THE SCIENCES), addresses the question about the defining specificity of scientific knowledge by differentiating between science and scientificity (Wissenschaftlichkeit), com- 
mending to trust in scientificity rather than in science. The obvious allusion of his title "In Science We Trust” to the US-American "In God we trust”, imprinted on each dollar note, highlights his observation that validity claims of the natural sciences have become the currency of ultimate trustworthiness in large parts of society. Albert Meier refutes this near religious status of knowledge produced by the natural sciences by critically assessing 13 key terms closely related to the semantic field of scientificity in an argumentative order. These are truth (Wahrheit), doubt (Zweifel), reason (Vernunft), realism (Realismus), relativism (Relativismus), per se/in itself (An sich), data and facts (Daten und Fakten), ancestrality (Anzestralität), metaphysics (Metaphysik), antagonism (Widerstreit), contextualism (Kontextualimus), rationality (Rationalität), and knowledge and scientificity (Wissen und Wissenschaftlichkeit).

He starts by outlining the relationship between the sciences, religious dogma, and the public in a history of doubting (Kant), which ultimately leads to the competition of incompatible knowledge formations like Western science and the knowledge of North American First Nations. The post-postmodern call in philosophy and literary studies for unambiguous knowledge is checked by the question of whether there are any independent facts to ultimately anchor knowledge in, a topic addressed centrally by the New Realism (Maurizio Ferraris). Instead of installing religion or mind-independent facts as 'transcendental signified' however, Meier suggests to differentiate between 'data' and 'facts' in order to assess scientific validity claims. Data would be for example the chemical formula for water, while the daily discourses about water that are embedded in cultural life-worlds are man-made, thus facts, from Latin 'facere/factum'. The transformation of data into meaningful facts - as the example shows -, thus always implies subjectivity, interests etc., which have to be approached in the natural and technical sciences and in the humanities with their specific methodologies. Meier sees an analogous differentiation at the basis of what French philosopher Quentin Meillassoux calls 'ancestrality'. Meillassoux criticises the 'correlationist' thesis prevalent in the humanities that relativises all knowledge with relation to the epistemic horizon of the knowing subject, and argues for the possibility of true objectivity in the natural sciences by pointing to Astrophysics and Palaeontology and their justified statements about 'ancestral' realities existing long before humanity.

However, despite these methodologically different premises, there are central similarities between the natural sciences and the humanities, for example with regard to their dependence on empirical reality, metaphysical foundations, and selfreflexive basic research. From this view, scientific knowledge does not qualify as science because it is 'true', but because it legitimises its validity claims through its methodology. With this premise, the conviction of North American First Nations to be the descendants of a mythical Buffalo would not be considered as scientific, but certainly as relevant knowledge because of its function, namely to explain their genesis and to derive ordering principles for their society and for their individual being in the world from this belief. The incompatibility of Western science and First Nations knowledge about the origin of the Cheyenne River Sioux in this context exemplifies 
a classical irresolvable 'Widerstreit' (antagonism/discord), based on irreconcilable intentionalities, which, however, is no intellectual scandalon, as it can be described rationally. Neither must this incompatibility necessarily lead to postmodern relativism, as Meier's references to Jocelyn Benoist make clear. For Benoist, all validity claims have to be contextualised by the function they acquire in specific settings: statements about a table will differ considerably from the various perspectives of everyday requirements, physics, or art history. The superiority of scientific knowledge production in comparison with the indigenous myths for Meier lies in its critical selfreflexivity. It is this self-reflexive rationality, which ultimately secures the scientificity of scientific knowledge production, and not the mostly short-lived 'truth' of scientific findings. Science in this sense, for Albert Meier following Niklas Luhmann, does not increase certainty, but uncertainty. The essay concludes with Rorty's dictum: "But there is nothing wrong with science, there is only something wrong with the attempt to divinize it." (80)

\section{Part II: Disciplinary Negotiations}

Paul Hoyningen-Huene, in his essay The Heart of Science: Systematicity, expounds his claim that "[s]cientific knowledge is primarily distinguished from other forms of knowledge, especially from everyday knowledge, by being more systematic" (85). Given the manifold context-bound aspects of such a claim, he starts his essay by various qualifications and reservations. Thus, he historicises the concept of 'science' by referring to past influences of non-Western knowledge traditions on what ultimately emerged as (Western) science. In a second step, his essay outlines historically specific concepts of scientificity from Plato to the present, with the conclusion that in light of the erosion of "belief in the existence of scientific methods" (87) the thesis of the uniqueness of scientific knowledge has to be addressed anew. In terms of systematics, Paul Hoyningen-Huene uses the term 'science' as an umbrella term not only for the natural sciences, but also for mathematics, social sciences, and the humanities, in analogy to the German term Wissenschaft. He further chooses a distinctly philosophical perspective, in explicit delimitation from a sociological approach. ${ }^{11}$ And finally he explains that his investigation is not aimed at differentiating science from metaphysics and pseudo-science, but to contrast it particularly with everyday knowledge. He further qualifies his thesis about the greater systematicity of scientific knowledge by stressing the comparative and relative nature of this claim, before clarifying the concept of 'systematicity' in concrete specifications of "nine contexts, or 'dimensions"” of scientific knowledge, "connected to each other by family resemblance relations” (90). These nine dimensions are 'descriptions', 'explanations', 'predictions',

11 See the contribution of Hubert Knoblauch in this volume, opting for a new empirical science of knowledge, combining a philosophy of science and sociological approaches. 
'the defence of knowledge claims', 'critical discourse', 'epistemic connectedness', 'an ideal of completeness', 'knowledge generation', and 'representation of knowledge'. Finally, Hoyningen-Huene outlines systematic flaws of historical definitions of scientific knowledge from Aristotle through Descartes, Kant, logical empiricism and critical rationalism to Thomas Kuhn and Paul Feyerabend, by showing that the individual shortcomings mostly consisted in a lopsided emphasis on one of the nine aspects he has explored in his essay.

Hans-HeinRich Trute, in his contribution On KNowledge and Law: The Role of LAW IN THE GENERATION AND HARMONIZATION OF KNOWLEDGE, addresses a topic that has been neglected hitherto in research because of the methodology of German legal theory. Legal knowledge relies on procedures, infrastructures and institutions generated by legal institutions themselves, which together supply a semblance of stability. Trute starts his analysis by outlining the classical model of jurisprudence, 'the doctrinal approach'. This rests on the premise that a central aspect of legal practice lies in extrapolating rules from texts by way of interpretation, which then are applied to facts. Thus, facts are subsumed under the texts of law. The most influential model of interpretation is the 'internal model', which assumes that the original intention of the author is deducible from the legal text, and that in this way the text already implies its application. Consequently, the entire legal system is understood not as a system of communication, but as a set of coherent assertions about legal texts. In analogy, facts are perceived as given and as clearly definable, if necessary with the help of experts. The process of transforming a social event into a legal case does not receive any attention in this approach.

In a next step, Trute presents common traits of non-classical approaches. These comprehend the legal text "as a transitory area of various interpretations" (107) and adhere to constructivist, processual notions of interpretation and knowledge production. Knowledge production is conceptualised as a variety of communicative procedures between social structures, legal meanings, and individuals. Trute addresses various agents in this communicative structure, like the publication system with its differentiated genres of legal texts, the court system with its hierarchical structure, lines of court decisions, text modules, the parties to a case, professional journals, and public hearings. Coverage through media opens another realm of knowledge production, contributing to the constant reflexive generation of continuity and variation by and of the law.

Public and especially administrative law for a long time seemed to be relatively stable, which Trute illustrates with reference to police law and its central notions of 'danger' and 'precaution'. However, this has changed due to developments like Europeanisation, internationalisation, environmental concerns, and market, financial and technical risk regulations. In such dynamic environments, the impression of continuity and stability vanishes, and new forms to generate theoretical and practical knowledge are established. Open procedures like public hearings may supply suffi- 
cient adjustment to actual needs for some time, but ultimately knowledge generating procedures are established, which are configured by law itself. Legal issues like market regulation of telecommunications, genetically modified products, and pharmaceutical issues would be current examples.

Additionally, specific infrastructures are institutionalised with the express purpose to produce knowledge on a permanent basis, like the European Food Safety Agency (EFSA), the European Statistics Authorities (ESS), the European Union Agency for Network and Information Security (ENISA), and the European Centre for Disease Prevention and Control (ECDC). A central problem of these networks as well as for example of European law is, how to secure a shared understanding of the respective rules despite widely divergent cultural and legal contexts and specific interests. Thus, a harmonisation of specific national administrations is necessary, while the possibility to act adequately in different contexts must be maintained. The chief instruments to meet this challenge are information networks, which ultimately aim at "establishing a cognitive structure” culminating in "a shared reality model” (116) concerning issues of administration and problem solution.

The last part of Trute's essay is dedicated to imminent changes that digitalisation might trigger in legal knowledge production. According to Trute, central changes have to be expected because of new publication procedures in the wake of digitalisation when, for example, court decisions are published indiscriminately and without contextualisation or systematisation. Another factor to fundamentally change legal knowledge production would be the incorporation of corpus linguistics as an ancillary science, as is already done in US courts. In this procedure, the use of words in a linguistic data base containing a variety of legal documents is traced and serves as the basis for actual interpretations of these terms - according to Trute a very problematic procedure to generate meanings. Attempts to establish more extensive uses for digitalised corpus linguistics fail due to the simplistic modelling of application procedures. Similar problems can be observed in strategies of digitalised profiling.

A vital issue concerning any kind of algorithmic knowledge in law is the problem of tracing and reproducing the genesis of the results. These difficulties can arise due to the limited access to the respective software, i. e. in the police and secret service sector, but they may also be due to the complexity of the respective software. Each of these cases, however, undermines the essential legal principle that any legal decision has to leave open the possibility to be revised.

Sabine MaAsen, in her essay InNovation und Relevanz: Forschung Im GeranGEL WIDERSTREITENDER ANFORDERUNGEN (INNOVATION AND RELEVANCE: RESEARCH IN A SCRAmble of Competing Demands), starts with the observation that innovation' has become a key concept not only in mainstream discourses concerning social well-being, but also in counter models like 'innovation of degrowth' and 'ecological innovation'. Increasingly, not basic research, but innovation has to legitimate scientific research in general, supposedly welding academic curiosity to social relevance. 
However, the major trait of innovation is disruption, causing irritation. To alleviate this effect, new research areas like 'Technology Assessment' and 'Citizen Science' are evolving. Thus, 'Responsible Research and Innovation' (RRI) has become a prominent topic of the European Commission's programme 'Horizon 2020', engendering a new architecture of shared responsibilities and of participatory knowledge production. This 'innovation of innovation' aims at combining disciplinary excellence and social - and that means transdisciplinary - relevance. However, especially for applicationoriented sciences this programme of science policy poses many problems, because the exclusive focus on pragmatic solutions continually necessitates new programmes. Maasen reconstructs RRI as one such programme, responding to a dynamics of constantly changing 'contracts' between science and society, and seeking a solution by supplementing the 'legitimation through innovation' by measures for the 'legitimation of innovation' (see 127).

These attempts form the current provisional end point of new 'contractual' relationships between science and society. Maasen outlines the chronology of such contractual developments from the linear model since 1945, when society was meant to supply the sciences with resources so they could contribute to technological progress, through the finalised model of the 1970s, aimed at generating a 'cartography of science politics' for a rational research politics, to the hybrid model emerging in the 1990. In this last model, science and society are intermingled, from the set-up of research programmes that are geared towards the needs of the potential users, to quality control by non-scientific criteria (see 129/130). In contradistinction to the 'linear' and the 'finalised' model with their radical or at least limited autonomy of science, the 'hybrid' model endorses a comprehensive consideration of extrinsic and non-scientific demands ("Mode 2"). A central problem of this model lies in the tension between the 'epistemic core' of scientific knowledge production and external requests. The suggestion to address this tension by an ethics external to the sciences proper manifests firstly in a cascade of reflexive programmatics, aimed at public understanding of the sciences and technological impact assessments, and secondly in the implementation of external instruments of control and the demand of funding institutions for explicit deliberations on sustainability and responsibility. According to Maasen, this division of ethical labour between the individual ethics of the researcher and an external network of control characterises the 'social innovation' of RRI. A central problem of this set-up lies in the difficulty to establish the best point of intervention into ongoing research, because on the one hand the more developed a technology is the more easily its consequences can be foreseen, yet on the other hand the possibilities to change its course diminish continuously the more advanced the developments have already become.

Two examples illustrate the potential and limits of coping strategies for these quandaries, namely the Human Brain Project (HBP) and Citizen Science projects, which aim to include non-scientific agents into research. The HBP relies on Ethics Management by establishing a specific cluster to monitor ethical, social, and philo- 
sophical aspects of the ongoing research. However, notwithstanding the ambitious agenda of this import of corporate ethics into Big Science projects, the procedure remains an add-on with little impact for the actual practice of scientific research.

Citizen Science projects imply a radical intervention into a research practice, which from the end of the nineteenth century onward assumed that objective, disinterested and reliable scientific knowledge can only be produced by certified and institutionally legitimised persons. Yet despite elaborate measures to include the knowledge of for example patients in 'Patient Science' (CSO), technical barriers limit their direct participation in knowledge production. Thus, in the EteRNA Project of the Carnegy Mellon and Stanford Universities, the activity of lay people is restricted to an online platform without access to the epistemic core of scientific knowledge production. Similarly, reality labs may legitimate the relevance of specific knowledge production in the social context, but they contribute little to explore or develop alternative, and that is innovative, knowledge.

Additionally, the political demands for social relevance and innovation are at odds with the stipulations concerning excellence. Maasen concludes her analysis with a detailed comparison of research primarily legitimated by criteria of relevance, and research conducted with excellence as the ultimate criterion of quality. Although science policy programmatically calls for the combination of social relevance with disciplinary excellence, there is no solution in sight for the competition between these two - hitherto incommensurate - quality markers as strategies to legitimate scientific knowledge production.

HUBERT KNOBLAUCH's contribution VON DER WISSENSGESELLSCHAFT ZUR EMPIRISCHEN WiSSENSCHAFTSTHEORIE (FROM THE KNOWLEDGE SOCIETY TO AN EMPIRICAL THEORY OF SCIENCE) can be read as a counterargument to Hoyningen-Huene's definition of scientific knowledge, holding that "the rise of the knowledge society [...] not only results in a dissemination of science, scientific knowledge and practices into society, but also and consequently in a transgression of the boundaries of science itself." (141, my translation)

Considering this situation, it is unfortunate that Knowledge Research - not widespread in Germany anyway -, has distanced itself from the Sociology of Science, which always perceives knowledge production as well as competing knowledges as a social conflict. With this premise, the sciences cannot be analysed as national communities, and the focus of Knowledge Research has to take into account that scientific research is progressively regulated by extrinsic rules and principles with regard to institutional structures as well as procedures of research and thought paradigms. In line with central tenets of the Knowledge Research outlined above, Knoblauch holds that the traditional focus on the monologically productive researcher or scholar does not capture this actual embeddedness of the sciences in social and political contexts, and he calls for a new theory of science that takes into account sociological empirical research. Knoblauch's essay drafts such a - yet to be implemented - new empirical 
theory of science "in order to critically clarify what we want to consider as scientific [knowledge production]" (141, my translation).

By way of introduction, Knoblauch outlines a sociological in contradistinction to a philosophical perspective on knowledge, ranging from Auguste Comte through Karl Marx, Karl Mannheim, Ludwik Fleck, and Thomas Kuhn to Berger/Luckmann, who finally hold that all knowledges - from the sciences through ideologies, religions and everyday convictions - are social constructs, which are disseminated, enforced and transmitted through specialised institutions with specific forms of legitimation according to class, gender etc.

This dissemination of knowledge leads to a scientification of non-scientific realms of society like economics, politics, religion, media, sports etc. Yet despite this growing appreciation of the academic sciences as symbolic capital, knowledge producing institutions have no decisive status in leading institutions of politics or economics. ${ }^{12}$ Just the opposite, economic parameters and political agendas as well as the media increasingly shape the structure and topics of the sciences. Thus, scientific knowledges are no closed system any more, but entangled with a host of other social structures. Knoblauch mentions the exorbitant relevance students' evaluations and third-party funding are granted in appointment committees, the all pervasive presence of PowerPoint presentations, science slams, and digitalisation, all of which have been transferred from economics into institutions of academic knowledge production. This progressive blurring of boundaries between scientific research proper and other knowledge systems harbours the danger of relinquishing the definition of scientificity and its function to 'codes' other than the search for truth.

Under these circumstances, the central question for Knoblauch - like for Hoyningen-Huene - is: How can the field of scientific knowledge be demarcated from other knowledge formations? Knoblauch opts for a model where the sciences themselves critically reflect on their normative tenets, conjoining the more classical perspective of the Philosophy of Science with their focus on the individual subject, and that of the Sociology of Science analysing scientific knowledge as a social phenomenon, in order to reciprocally correct the respective methodologically limited horizons. The focus of this interdisciplinary connection of a Philosophy of Science with the empirical Sociology of Scientific Knowledges should simultaneously lie on the normative aspects of the Philosophy of Science like methodological rules, and on the social dimension of scientific knowledge from the production to the legitimation of their results. Finally, Knoblauch sketches four requirements such an interdisciplinary empirical theory of scientific knowledge would have to fulfil, one of which concerns a communicative model of knowledge production in analogy to Habermas' model of communication (Seminarmodell der Kommunikation) (see 153).

Such a critically self-reflexive discourse according to Knoblauch is imperative in order to preserve the authority of the sciences to determine themselves the scientific-

12 For a relativisation of this claim see the essays by Rudolf Stichweh and Konrad Ott in this volume. 
ity of scientific knowledge, and to fend off the multiple encroachments of economics and politics on their research and ways of knowledge production.

\section{Part III: Competing Knowledges in Politics}

Rudolf Stichweh, in his essay Wissen und das Politische System (KNowledge AND THE Political System), investigates the function of knowledge in political systems. In feudal systems, the attainment of political power was bound to rank, while the acquisition of knowledge was focussed on embodied practices like military skills or dancing to enforce a physical habitus. Administrative and advisory functions bound to knowledge requirements were also mostly recruited from the nobility, so their knowledge was a positive add-on, but not the indispensable condition for their position. Social advancement by knowledge was a rarity, with a remarkable exception being Thomas Cromwell, son of a blacksmith, who became the most important advisor of Henry VIII in England.

The democratic revolution from the eighteenth to the twenty-first century increased the value of knowledge in politics fundamentally, for example by the inclusion of the public and observer roles (Publikumsrollen). This means that the public in the role of the observer commands strategic possibilities of intervention, which influence the selection and the action of persons in operative positions (operative Funktionen). In the case of politics, this is first and foremost the electoral power. In order to participate in politics, the citizen is expected to be 'well informed'. However, this requirement does not presume any kind of institutional education, but it is assumed to be fulfilled as soon as someone is included in the political system. This reasoning rests on the premise that all members of a society in their role as observers become competent lay sociologists by their daily mastery of social reality. In this way, the ability to contribute knowledge to the political process is attributed to each member of the respective society. The contrafactual aspect that the increasing complexity of political constellations is not met by sufficient knowledge on the side of the citizens is countered by politics through the permanent expansion of educational institutions.

Like any other functional system in modern societies, the political system - apart from the public observer roles (Publikumsrollen) - consists of a highly differentiated stratum of performance roles (Leistungsrollen). The function and semantics of knowledge in these strata is dependent on the respective political system with fundamental differences between authoritarian and democratic systems. In democracies, the boundary between the public and achievement functions is permeable to various degrees, illustrated by Rudolf Stichweh with the example of Switzerland.

However, these performance roles (Leistungsrollen) have nowhere developed into a political profession bound to specific knowledge. Instead, proximity to a political party takes the role of social status and professional knowledge. Under these circumstances, the knowledge of the political agents refers to the knowledge of the party pro- 
grammes and strategies of how to utilise them for their own ends. Under conditions of a majority voting system, the candidates have to know how to manage the diversity of their electorate, but here also no specifically political knowledge is necessary. Thus, party politics as well as the conditions of local electoral campaigns inhibit a professionalisation of performance roles (Leistungsrollen) in politics. Even more fundamentally, the idea that the performance roles are simply authorised representatives of the observing roles (Publikumsrollen) and can be countermanded at any time, makes the formation of a privileged knowledge system highly improbable.

For the reasons outlined above, politics needs experts. Access to knowledge is organised by way of experts, no matter whether the issues arise from societal problems like climate change, or whether they refer to genuine political tasks like foreign politics. Rudolf Stichweh explicates two ways of strategically embedding experts into politics, namely to generate experts from inside the respective party system, or to recruit experts from non-political organisations. Similarly, politics can address the constant diversification and multiplication of problems in all function systems of society like law, religion, economics, and education in two ways: They can either be incorporated into the realm of politics, or they can be relegated to experts of the respective function system. In the latter case, the outsourced decisions are still political decisions insofar as they effect those collective binding forces typical for political systems. Stichweh illustrates this increasing relegation into autonomous decision-making groups with the function of Central Banks and Constitutional Courts. In organisations like these, as soon as political institutions have taken staff decisions, the respective organisation henceforth decides autonomously about politically significant issues like the legality of political decisions or interest rates. Additionally, in the twentieth and twenty-first century there is a growing number of function systems that act as a bridge between expert knowledge and political issues, like autonomous and yet public universities, or the international panel on climate change.

In conclusion, Rudolf Stichweh outlines a general model for the relationship between various expert knowledges and politics. In this model, the centre of a political system is held by politically responsible players who are able to win elections, framed by two peripheries: One is the electorate of supposedly well informed citizens, the other is made up of experts and autonomous expert organisations, who are connected in various ways to the political centre. In this model, the absence of expert knowledge at the centre of the system is the condition for the flexibility to connect with extremely diversified knowledge systems; the ignorance of the centre thus secures the learning capability of the dynamic system as a whole.

KonRAD OTt, in his article ZuR EINLAGERUng HOCHRADIOAKTIVER RESTSTOFFE AUS ETHISCHER UND POLITISCHER Sicht: BESTANDSAUfNAHME UND AUSSICHT (ThE Deposit of Highly Contaminated Radioactive Waste from an Ethical and Political Perspective: Survey and Prospect), gives a concrete example for the ethical and political problems involved in participatory knowledge production. His 
example is the search for a final repository for radioactive waste in order to generate a basis for a political decision. Konrad Ott was a member of the group ENTRIA (Entsorgungsoptionen für radioaktive Reststoffe: Interdisziplinäre Analysen und Entwicklung von Bewertungsgrundlagen / Disposal Options for Radioactive Residues: Interdisciplinary Analyses and Development of Evaluation Principles), a research group of twelve disciplines from the humanities and the natural, engineering, legal and social sciences, which was funded by the BMBF (Bundesministerium für Bildung und Forschung / Federal Ministry of Education and Research) 2013-2017. His analysis of participatory knowledge production for political counselling is based on his experiences in this context.

The entire discussion was framed by the history of arguments against the nonmilitary use of nuclear energy starting in the 1970s in Germany, which in 2011 - after Fukushima - made Chancellor Angela Merkel declare the withdrawal from nuclear energy. This decision changed the foundation of all political debates about the ultimate repositories of highly radioactive waste and forced supporters and opponents alike to adopt a prospective perspective.

Ott starts his deliberation with the normative observation that "states are communities of inter-generational liability" (172, my translation). The search for a final deposit is lead by two central conditions: 1) to find a place in Germany which meets the security standards, and 2) which is acceptable for the people immediately affected by a deposit 'in their back yard'. The 'wicked problem' consists in the fact that no decision will meet the desired normative standards entirely. This situation shapes the communication about the problem. Ethical, scientific, and technological knowledge, legal and political considerations as well as psychological skillfulness all are necessary to produce knowledge that can serve as the basis for a political decision with farreaching consequences in the near and the unforeseeable future - the law requires one million years of security from any harm through nuclear waste (StandAG 2, § 1.2). Radioactive waste is classified as 'negative goods', and Ott outlines argumentative lines of how to deal with this negative good, like distribution on as many shoulders as possible, concentrated storage, possible forms of compensation for the residents of the repository, duck-and-cover policies of waiting for more secure scientific knowledges, and participatory (democratic) or exclusivist (nuclear industry) procedures in conducting the search.

The negotiations were guided by two ethical norms, namely security and justice, both of which are expounded in detail in the two main chapters of the essay. Addressing the security aspect first, Ott differentiates between safety, i. e. protection from nuclear radiation, and security proper, meaning protection from unauthorised access. Qualifiers like ‘best possible protection' can only be understood as elative, never as superlative, because of the uncertainty of the sciences to find one best possibility, and the resulting necessity to always take various deposit sites into consideration. The ultimate decision thus will have to be taken by politics. Ott elaborates several criteria to be heeded for best possible security, explicates the minimax principle - 
namely to minimise various hazards for the public in case of toxic radiation escaping from the deposit -, and considers the relation of risk and danger from the perspective of the directly affected citizens. He relates these argumentative lines to scenarios in the near and in the far future, for example postponing the decision in order to gain more scientific certainty for the price of increased risks in the actual present, with the waste stored under insecure conditions. Finally, Ott addresses the role of costs, which debunks the discourse of 'cheap nuclear energy' as 'techno-legend'.

The second major aspect of generating decisive knowledge with relation to finding a permanent repository for radioactive waste is justice. Following Aristotle, Ott distinguishes between political, distributive, and commutative justice, and introduces six aspects, all of which have to be met, like procedural, compensatory, and legal justice as well as the obligation to do justice to future generations. Ott explicates, in which ways the ENTRIA group met these aspects and sketches concomitant problems with view to long-term responsibility, for example leaving open to future generations the option of reversing the decisions taken today, which unfolds a whole new set of possibilities and dangers concerning safety and security. In conclusion, Konrad Ott offers a defensible position from the perspective of philosophical ethics in light of the arguments developed in the essay.

Falko Schnicke, in his contribution 'It IS DANGERous to GenERALISE About STATE VISITS': PRAKTIKEN DES WISSENS IN DER BRITISCHEN AUSSENPOLITIK DES 20. Jahrhunderts ('It is Dangerous to Generalise About State Visits': Practices of Knowledge Production in 20 ${ }^{\mathrm{TH}}$-Century British Foreign Policy), presents a case study of two modes of knowledge production concerning state visits in Britain during the twentieth century, with special emphasis on the first visit of Theodor Heuss after WWII in 1958. For Schnicke, following Philip Sarasin, knowledge comprises the social systematisation and circulation as well as the agents of knowledge. It is understood as a resource and a 'utility' (Drunker) for practical action, and it allows to organise and change, but also to avert changes from one's world, ultimately consisting of shifting constellations of various knowledge formations (Adolf/Stehr, Burke, Klausnitzer). The essay traces processes leading to normative definitions of the functional as well as ceremonial aspects of state visits.

Schnicke distinguishes between the phase of 'practices of actualising knowledge' till the 1960s, and the phase of 'systematizing knowledge' from the 1960s onward. The former specified the organisation of state visits in case-by-case decisions, which simply modified former practices according to circumstances. 'Systematizing knowledge' largely replaced this practice by establishing normative rules and rituals, and by institutionalising this form of knowledge production through the foundation of a 'Royal Visits Committee' in 1962. This committee professionalised the organisation of state visits in many aspects and was equipped with extensive decision-making authority and communicative reach. They established and disseminated a detailed typology of visits. Additionally, in 1976 the Royal Visits Committee in a memorandum 
with the title "Value of State Visits Overseas" for the first time discussed the function of state visits and proposed a variety of accompanying measures to further British values, alliances, and economics. In these propositions, the Royal Family figured as (only) a function in the plans of the Royal Visits Committee. At the same time, the memorandum insisted on the possibility to modify the ceremonies according to individual circumstances. As a conclusion, Schnicke outlines the merits of research approaching state visits from a perspective of knowledge history, which for example illustrates the value of a lack of knowledge as a dynamic force to instigate change, and as a bulwark against an overdetermination of diplomatic practices by rigid rules.

\section{References}

Abel, G. (2012). Knowledge Research: Extending and Revising Epistemology. In: idem and J. Conant. Eds. Rethinking Epistemology (Berlin Studies in Knowledge Research 1). Hamburg, Boston: de Gruyter, 1-52.

Abeysekara, A. (2013). At the Limits of the Secular: History and Critique in Postcolonial Religious Studies. In: G. Huggan. Ed. The Oxford Handbook of Postcolonial Studies. Oxford: Oxford University Press, 506-520.

Adler, H. (2013). Horizont und Idylle: Aspekte einer Gnoseologie von Aisthesis und Noesis. In: idem and L. L. Wolff. Eds. Aisthesis und Noesis: Zwei Erkenntnisformen vom 18. Jahrhundert bis zur Gegenwart. München: Wilhelm Fink, 25-42.

Ahmad, A. (1992). In Theory: Classes, Nations, Literatures. London: Verso.

Baumgarten, A. G. (2007 [1750]). Ästhetik. Ed. and translated by D. Mirbach. Hamburg: Meiner.

Blumenberg, H. (1993). Light as a Metaphor for Truth: At the Preliminary Stage of Philosophical Concept Formation. In: D. M. Levin. Ed. Modernity and the Hegemony of Vision. Berkeley: University of California Press, 30-62.

Bourdieu, P. (1989). Social Space and Symbolic Power. Sociological Theory 7(1), 14-25.

Brendel, E. and U. Gähde (2016). Was ist Wissen? In: W. Buchmüller and C. Jakobeit. Eds. Erkenntnis, Wissenschaft und Gesellschaft. Wie Forschung Wissen schafft. Berlin, Heidelberg: Springer, 9-21.

Byatt, A. S. (1991). Possession: A Romance. London: Vintage.

Chakrabarty, D. (2000). Provincializing Europe: Postcolonial Thought and Historical Difference. Princeton/NJ, Oxford: Oxford University Press.

Chatterjee, P. (1986). Nationalist Thought and the Colonial World: A Derivative Discourse? London: Zed.

Comaroff, J. and J. L. Comaroff (2016). Theory from the South: Or, how Euro-America is Evolving Toward Africa. Oxon, New York: Routledge.

Daston, L. (1991). Marvelous Facts and Miraculous Evidence in Early Modern Europe. Critical Inquiry 18 (1), 93-124.

Daston, L. and P. Gallison (2007). Objectivity. New York: Zone Books.

Detel, W. (2014). Wissenskulturen und epistemische Praktiken. In: H. J. Sandkühler. Ed. Wissen: Wissenskulturen und die Kontextualität des Wissens. Frankfurt/Main: Peter Lang, 72-89.

Devy, G. (1992). After Amnesia: Tradition and Change in Indian Literary Criticism. London: Sangam.

Devy, G., G. Davis, and K. K. Chakravarty. Eds (2014). Knowing Differently: The Challenges of the Indigenous. Delhi: Routledge. 
Episkenew, J.-A. (2009). Taking Back Our Spirits: Indigenous Literature, Public Policy, and Healing. Winnipeg: University of Manitoba Press.

Fanon, F. (1980 [1952]). Schwarze Haut, weiße Masken. Transl. from French by E. Moldenhauer. Frankfurt/Main: Syndikat.

Fleck, L. (1935). Entstehung und Entwicklung einer wissenschaftlichen Tatsache: Einführung in die Lehre vom Denkstil und Denkkollektiv. Basel: Schwabe [First translation into English (1979). Genesis and Development of a Scientific Fact. Ed. by T. J. Trenn and R. K. Merton, translated by F. Bradley, with a foreword by T. Kuhn. Chicago: University of Chicago Press].

Foucault, M. (1980). Truth and Power. In: idem, Power/Knowledge: Selected Interviews and Other Writings 1972-1977. Ed. by C. Gordon, translated by C. Gordon, L. Marshall, J. Mepham, K. Soper. New York: Pantheon Books, 109-133.

Foucault, M. (1981). The Order of Discourse. In: R. Young. Ed. Untying the Text: A Post-Structuralist Reader. Boston et al.: Routledge, 51-78.

Foucault, M. (2013). Lectures on the Will to Know: Lectures at the Collège de France 1970-1971 and Oedipal Knowledge. Ed. by A. I. Davidson, translated by G. Burchell. Basingstoke: Palgrave Macmillan.

Gess, N. and S. Janßen. Eds (2014). Wissens-Ordnungen: Zu einer historischen Epistemologie der Literatur. Berlin: De Gruyter.

Grenfell, M. and D. James (2004). Change in the Field - Changing the Field: Bourdieu and the Methodological Practice of Educational Research. British Journal of Sociology of Education 25(4), 507-523.

Horatschek, A. M. (2008). Zur Einführung: Der Britische Roman als Genre der Lebenskunst. In: idem, S. Bach, S. Glomb, and S. Horlacher. Eds. Literatur und Lebenskunst. Reflexionen zum guten Leben im britischen Roman vom Viktorianismus zur Postmoderne (Studies in English Literary and Cultural History 30). Trier: Wissenschaftlicher Verlag Trier, 1-16.

Hörisch, J. (1988). Die Wut des Verstehens: Zur Kritik der Hermeneutik. Frankfurt/Main: Suhrkamp. Hörisch, J. (2007). Das Wissen der Literatur. München: Wilhelm Fink.

Kant, I. (1998 [1781/1787]). Critique of Pure Reason. Translated by P. Guyer and A. W. Wood. Cambridge: Cambridge University Press.

Keats, J. (1958 [1817]). The Letters of John Keats, 1814-1821. Ed. by H. E. Rollins. Cambridge/MA: Harvard University Press (2 vols.).

Kley, A. (2018). What Literature Knows: An Introduction. In: idem and K. Merten. Eds. What Literature Knows: Forays into Literary Knowledge Production. Berlin et al.: Peter Lang, 9-26.

Kuhn, T. (1962). The Structure of Scientific Revolutions. Chicago: Chicago University Press.

Lal, V. (2003). The History of History: Politics and Scholarship in Modern India. Oxford: Oxford University Press.

Lal, V. and A. Nandy. Eds (2005). The Future of Knowledge and Culture: A Dictionary for the $21^{\text {st }}$ Century. New Delhi: Penguin.

Latour, B. (1979). Laboratory Life: The Social Construction of Scientific Facts. Beverly Hills: Sage.

Latour, B. (1988 [1984]). The Pasteurization of France. Translated by A. Sheridan and J. Law. Cambridge/MA, London: Harvard University Press.

Lenzen, M. (2011). Die Lehre vom Nichtwissen: Alles, was man nicht wissen muss. Frankfurter Allgemeine Zeitung, June $9^{\text {th }}$; https://www.faz.net/aktuell/feuilleton/geisteswissenschaften/ die-lehre-vom-nichtwissen-alles-was-man-nicht-wissen-muss-1653324.html [24.10.2019].

Lutz, H. (2018). “They Talk, We Listen”: Indigenous Knowledges and Western Discourse. Zeitschrift für Kanada-Studien 67, 66-88.

McQuillan, J. C. (2015). Kant's Critique of Baumgarten's Aesthetics. Idealistic Studies 45(1), 69-80 [DOI: 10.5840/idstudies2015102340]. 
Mersch, D. (2013). Nichtpropositionalität und ästhetisches Denken; https://

dieter-mersch.de/.cm4all/iproc.php/\%C3\%84sthetik\%20Kunstphilosophie/Mersch_ Nichtpropositionalita\%CC\%88t\%20und\%20a\%CC\%88sthetisches\%20Denken_2013.pdf [24.10.2019].

Mersch, D. (2015). Epistemologien des Ästhetischen. Zürich, Berlin: Diaphanes.

Miller, J. H. (1987). An Ethics of Reading. Style 21(2), 181-191.

Mirbach, D. (2007). Einführung zur fragmentarischen Ganzheit von Alexander Gottlieb Baumgartens Aesthetica (1750/58). In: A. G. Baumgarten, Ästhetik. Ed. and translated by D. Mirbach. Hamburg: Meiner, Vol. 1: XV-LXXX.

Mukherjee, P. (2011). Surfing the Second Wave: Amitav Gosh's The Hungry Tide. In: L. Connell and N. Marsh. Eds. Literature and Globalization: A Reader. London, New York/NY: Routledge, 177-189.

Nanda, M. (2003). Prophets Facing Backward: Postmodern Critiques of Science and Hindu Nationalism in India. New Brunswick/NJ, London: Rutgers University Press.

Nandy, A. (1983). The Intimate Enemy: Loss and Recovery of Self under Colonialism. Delhi: Oxford University Press.

Nandy, A. (2000). Recovery of Indigenous Knowledge and Dissenting Futures of the University. In: S. Inayatulla and J. Gidley. Eds. The University in Transformation: Global Perspectives on the Futures of the University. Westport/CT: Bergin \& Garvey, 115-123.

Nate, R. (2009). Wissenschaft, Rhetorik und Literatur: Historische Perspektiven. Würzburg: Königshausen Neumann.

Nate, R. (2018). “The Pleasing Visions I had Formed”: Natural Knowledge and Self-Awareness in Jonathan Swift's Satires. In: A. Kley and K. Merten. Eds. What Literature Knows: Forays into Literary Knowledge Production. Berlin: Peter Lang, 45-63.

Ngũgĩ wa Thiong’o (1986). Decolonising the Mind: The Politics of Language in African Literature. Portsmouth/NH: Heinemann.

Nünning, V. (2014). Reading Fictions, Changing Minds: The Cognitive Value of Fiction. Heidelberg: Universitätsverlag Winter.

Plato (1961). Theaetetus, Sophist. Tansl. by H. N. Fowler [1 $1^{\text {st }}$ edition 1921]. Cambridge: Harvard University Press.

Prakesh, G. (1999). Another Reason: Science and the Imagination of Modern India. Princeton/NJ: Princeton University Press.

Ratté, L. (2012). Unlikely Encounters: Fiction and Scientific Discourse in the Novels of Amitav Ghosh. In: C. Sankaran. Ed. History, Narrative, and Testimony in Amitav Ghosh's Fiction. Albany/NY: State University of New York Press, 17-32.

Rößler, H. (2012). Die Kunst des Augenscheins: Praktiken der Evidenz im 17. Jahrhundert. Berlin: LIT.

Rorty, R. (1991). Objectivism, Relativism and Truth (Philosophical Papers 1). Cambridge/MA: Cambridge University Press.

Sandkühler, H. J. (2012). Critique of Representation: Cultures of Knowledge - Humanly Speaking. In: G. Abel and J. Conant. Eds. Rethinking Epistemology (Berlin Studies in Knowledge Research 1). Hamburg, Boston: de Gruyter, 173-193.

Sandkühler, H. J. (2014). Wissenskulturen: Zum Status und zur Funktion eines epistemologischen Konzepts. In: idem. Ed. Wissen: Wissenskulturen und die Kontextualität des Wissens. Frankfurt/ Main: Peter Lang, 59-72.

Schützeichel, R. Ed. (2007). Handbuch Wissenssoziologie und Wissensforschung. Konstanz: Universitätsverlag Konstanz. Including art. "Max Scheler”: 55-76, art. "Soziale Epistemologie”: 290-305, art. "Soziologie des wissenschaftlichen Wissens": 306-327.

Shapin, S. (1994). A Social History of Truth: Civility and Science in Seventeenth-Century England. Chicago/IL: University of Chicago Press. 
Spivak, G. C. (1988). Can the Subaltern Speak? In: C. Nelson and L. Grossberg. Eds. Marxism and the Interpretation of Culture. Basingstroke: Macmillan, 271-313.

UNESCO (2005). Towards Knowledge Societies: UNESCO World Report. Paris: UNESCO Publishing. Weiler, H. N. (2009). Whose Knowledge Matters? Development and the Politics of Knowledge. In: Th. Hanf, H. N. Weiler, and H. Dickow. Eds. Entwicklung als Beruf. Baden-Baden: Nomos, 485-496; https://web.stanford.edu/ weiler/Texts09/Weiler_Molt_09.pdf [24.10.2019].

Zizek, S. (2009). Appendix: Multiculturalism, the Reality of an Illusion; www.lacan.com/ essays/?page_id=454 [24.10.2019]. 